\title{
Methods to detect DNA damage by free radicals: relation to exercise
}

\author{
Henrik E. Poulsen ${ }^{1 *}$, Allan Weimann ${ }^{1}$ and Steffen Loft ${ }^{2}$ \\ ${ }^{1}$ Department of Clinical Pharmacology, Rigshospitalet, University Hospital Copenhagen, Denmark \\ ${ }^{2}$ Department of Public Health, Panum Institute, Health Science Faculty, Copenhagen University, Denmark
}

\begin{abstract}
Epidemiological investigations repeatedly show decreased morbidity from regular exercise compared with sedentary life. A large number of investigations have demonstrated increased oxidation of important cellular macromolecules, whereas other investigators have found no effects or even signs of lowering of oxidation of macromolecules. In particular, extreme and longduration strenuous exercise appears to lead to deleterious oxidation of cellular macromolecules. The oxidation of DNA is important because the oxidative modifications of DNA bases, particularly the 8-hydroxylation of guanine, are mutagenic and have been implicated in a variety of diseases such as ageing and cancer. The methodologies for further investigation of the relationship between DNA oxidation and exercise are available. The preferred methods rely on HPLC or GC-mass spectrometry; whereas the theoretically-attractive liquid chromatographytandem mass spectrometry is being developed. Caution should be taken to avoid artifacts because of the six orders of magnitude of difference between oxidized and non-oxidized DNA bases in tissues. The methods can be used to estimate tissue levels, i.e. a local concentration of oxidized DNA, or to estimate the rate of body DNA oxidation by the urinary output of repair products, the latter being a method that is independent of repair. During exercise there appears to be a shifting of dietary-dependent antioxidant, e.g. vitamin C and vitamin E, from muscle to plasma, and an increased oxidation in plasma of these antioxidants. Supplementation trials with antioxidants have not been able to increase exercise performance; however, optimum nutrition with antioxidants and possibly supplementation, could be important in the prevention of diseases in the long term. The pattern from these observations appears to be quite consistent; immediately after exercise, regardless of how intense, there do not appear to be any signs of oxidative damage to DNA. Acute or prolonged moderate exercise does not produce signs of oxidative DNA damage and might even be associated with lowering of the levels of oxidation of tissue DNA; however, after long-duration and intense exercise an increase in oxidative DNA modifications is apparent. We suggest as a hypothesis that the relationship between exercise and health is U-shaped. This hypothesis needs to be tested in detail in order to establish the maximum beneficial exercise level with regard to oxidative DNA modification, and also the level that could be deleterious and might even increase the risk for cancer and other diseases.
\end{abstract}

Antioxidants: DNA oxidation: Exercise: 8-Oxo-7,8-dihydro-2'-deoxyguanosine

Exercise or similar physical activity increases the requirement for $\mathrm{O}_{2}$. Cellular respiration is a tightlycontrolled process in which $\mathrm{O}_{2}$ undergoes a four-electron reduction to water. A small proportion (Chance et al. 1979) of the $\mathrm{O}_{2}$, however, undergoes single electron transfer producing the superoxide radical, $\mathrm{H}_{2} \mathrm{O}_{2}$, hydroxyl radical and finally water. The superoxide radical and the hydroxyl radical have by definition an unpaired free electron and are highly reactive, whereas $\mathrm{H}_{2} \mathrm{O}_{2}$ is not a free radical. Collectively, these metabolites are termed reactive oxygen species (ROS) and similarly the nitrogen metabolites are termed reactive nitrogen species (Wiseman \& Halliwell, 1996).

ROS were originally and still are considered damaging species that could induce changes to important cellular macromolecules and be related to particular diseases. Thus, ROS-induced changes in lipids could lead to oxidation of LDL and thereby to arteriosclerosis (Esterbauer et al. 1992), and ROS-induced changes to DNA could lead to cancer (Ames \& Saul, 1986) and ageing (Ames \& Shigenaga, 1992) 
by a variety of events (Poulsen et al. 1998a). Further to the deleterious effects of ROS, it now appears that ROS and reactive nitrogen species can function in biological signalling, as exemplified by NO, and it has been suggested that ROS are important for signal transduction pathways (Palmer \& Paulson, 1997). Research in recent years has suggested that physical activity modulates the immune system. These findings indicate that the response to exercise is quite complex, a notion that is supported by studies on exercise and immune function showing that during moderate and severe exercise the immune system is enhanced, and only intense long-duration exercise produces immunosuppression (Pedersen et al. 1996). It has been demonstrated that with age there is increased oxidative damage to DNA, lipids and proteins in human skeletal muscle, thus providing evidence of a role for oxidative damage in human ageing (Mecocci et al. 1999). We have shown that intense exercise for $30 \mathrm{~d}$ leads to an increased rate of formation of oxidative modifications of DNA (Poulsen et al. 1996). By contrast, we were unable to find any signs of DNA modification as a result of acute exhaustive exercise (Nielsen et al. 1995).

On this basis, the increased $\mathrm{O}_{2}$ consumption due to exercise, in the absence of other factors, should increase the risk of arteriosclerosis, cancer and premature ageing. However, it is quite evident from a large number of epidemiological studies (for example, see Paffenberger et al. 1993) that regular and moderate exercise is associated with low risk of these diseases. Moreover, change in physical fitness in healthy middle-aged men is a strong predictor of mortality, even small improvements in physical fitness are associated with a significantly lower $(P<0.05$; two-tailed) risk of death (Erikssen et al. 1998). Evidence has been accumulating that physically-active individuals have a decreased rate of all-cancer mortality, and in particular for cancer of the colon, breast and perhaps prostate (Lee et al. 1997; Oliveria \& Christos, 1997; Kiningham, 1998). Thus, the data available are to some extent conflicting. The purpose of the present review is to summarize the present knowledge relating to exercise and oxidative modification of DNA, and to outline the methodologies for measuring DNA oxidation, to highlight pitfalls and to indicate how to interpret different measurements, to suggest hypotheses for the relationship between exercise and DNA oxidation, and to identify possible methods of testing the hypotheses.

\section{Oxidative damage to DNA}

The oxidative modification of DNA was a serendipitous discovery made during an investigation of the effects of heating food on DNA modifications (Kasai \& Nishimura, 1984), and was also independently discovered in another laboratory (Dizdaroglu, 1985). It is now clear that among the more than 100 different oxidative modifications to DNA that have been described (Cadet et al. 1994; Dizdaroglu, 1994) the dominant oxidative modification present is the 8-hydroxylation of guanine, 8-oxo-7,8-dihydro-2'deoxyguanosine (8-oxodG). It has been clearly demonstrated that some of these modifications are biologically relevant because of their relative frequency of occurrence (Kasai, 1997), because they are mutagenic (Retèl et al.
1993) and because specific repair enzymes have been found (Bessho et al. 1993). It is quite evident from simple basic calculations and estimated rates of oxidation of guanine from urinary excretion (Poulsen et al. 1998a) that extensive repair of such lesions is absolute mandatory for survival. Several DNA repair enzyme systems have been described in various systems; however, a detailed description of DNA repair systems in human subjects in vivo is not presently available, and methods for the direct estimation of the quantitative importance of various DNA repair systems in vivo are still in the development phase.

The levels of oxidative modifications of DNA in tissues are subject to intense discussion, because of considerable variation between laboratories (for detailed review, see Loft \& Poulsen, 1996). The published values from different laboratories vary by several orders of magnitude, and the true values are still the subject of debate (Lunec, 1999). Currently there is only systematic information about 8-oxodG levels in a variety of tissues (for review, see Loft \& Poulsen, 1996) and the influence of a variety of factors (for review, see Loft \& Poulsen, 1998). The major reason for this emphasis on measuring 8-oxodG is based on methodology. 8-OxodG is electrochemically active and can readily be measured by HPLC-electrochemical detection (EC; Loft et al. 1992; Poulsen et al. 1999b). Determination of modifications of other nucleosides requires more elaborate technology, e.g. GC-mass spectrometry (MS) or liquid chromatography-tandem MS.

Oxidative DNA modifications have been implicated in many pathophysiological processes, and have been implicated particularly as important in the development of cancer and ageing (Halliwell, 1994). Presently, however, there is only mechanistic and indirect evidence, and the predictive value of levels of oxidative DNA modification in relation to disease development remains to be established. Likewise, the evidence for a pathophysiological role for oxidative DNA modification in the deleterious effects of exercise has not been fully established.

\section{Methodologies of estimating oxidative DNA modification}

\section{HPLC-electrochemical detection}

The methodologies that can be used to estimate oxidative DNA modifications are listed in Table 1, which also indicates the biological matrix in which the methods can be used. The most universally applied methodology is measurement of 8 -oxodG by HPLC-EC. This method is mainly used for tissue DNA or cellular DNA (Kasai, 1997; Loft \& Poulsen, 1998), but in a more complicated set-up with column switching it can also be applied to urine (Loft et al. 1992; Loft \& Poulsen, 1998; Poulsen et al. 1999b). The analysis requires that 8 -oxodG is measured by electrochemical detection in tandem with u.v. detection of deoxyguanosine. The concentration of 8-oxodG should be given as number of molecules per $10^{5}$ molecules deoxyguanosine as recommended by ESCODD (Lunec, 1999), rather than relative to total DNA. The HPLC analysis requires isolation and digestion of genomic DNA, a potentially artifactual procedure (Collins et al. 1997a; Hofer $\&$ Moller, 1998). The exact value of normal organ DNA 
Table 1. Methods for measuring oxidative DNA modification

\begin{tabular}{|c|c|c|c|}
\hline Method & Measurement & Biological matrix & Reference \\
\hline HPLC-EC and u.v. & 8-oxodG, dG & Urine, DNA & $\begin{array}{l}\text { Shigenaga et al. (1989), Loft et al. (1992), Loft \& Poulsen (1998), } \\
\text { Poulsen et al. (1999b) }\end{array}$ \\
\hline HPLC-u.v. & $\mathrm{dTg}, \mathrm{Tg}$ & Urine & Adelman et al. (1988), Ámes et al. (1993) \\
\hline GC-MS & $>100$ modifications & DNA & \\
\hline${ }^{32} \mathrm{P}$ post-labelled-HPLC & 8-oxodG & DNA & Schuler et al. (1997), Moller et al. (1993) \\
\hline Alkaline elusion & 8-oxodG & DNA & Pflaum et al. (1997) \\
\hline \multirow[t]{3}{*}{ Comet assay } & 8-oxodG & DNA & Adelman et al. (1988), Ames et al. (1993), Collins et al. $(1996,1997)$ \\
\hline & Oxidized purines & DNA & \\
\hline & Oxidized pyrimidines & DNA & \\
\hline Immunological & 8-oxodG & Plasma, DNA, urine & Prieme et al. (1996) \\
\hline
\end{tabular}

EC, electrochemical detection; MS, mass spectrometry; 8-oxodG, 8-oxo-7,8-dihydro-2'-deoxyguanosine; dG, deoxyguanosine; dTg, deoxythymidine glycol; Tg, thymidine glycol.

oxidation levels is subject to considerable debate (Lunec, 1999). The levels reported in the literature are highly variable (Loft \& Poulsen, 1996) and a first effort at standardization in Europe revealed variation between different laboratories of about 180-fold for analysis of pig liver (Lunec, 1999). It is still undecided as to which levels are most accurate; however, several researchers consider the high levels measured by GC-MS to be unreliable and have highlighted the possibility of artifacts by this method (Poulsen et al. 1998b). The possibility of artifacts in the GC-MS procedure have been demonstrated by Ravanat et al. (1995).

With regard to the investigation of exercise, the HPLC-EC method for analysis of 8-oxodG is so far the only method employed.

\section{GC-mass spectrometry}

The virtues of the GC-MS estimation of oxidative DNA modifications are multiple. First, a huge array of different DNA modifications can be characterized and quantified, the method is sensitive and specific, and by the use of isotopically-labelled standards it is possible in one run to quantify several oxidation products (Dizdaroglu \& Bergtold, 1986; Dizdaroglu, 1991, 1992, 1993, 1994). However, there are several drawbacks in the methodology. First, the technique requires highly skilled and specialized personnel, the cost of the instruments is considerably higher than, for example, that of HPLC-EC, and few of the isotopicallylabelled internal standards are commercially available because skilled chemists are required to synthesize the relevant substances. GC-MS has been used mainly for tissue DNA analysis, and the sensitivity is about 0.1 molecule 8-oxodG per $10^{5}$ molecules deoxyguanosine, with a requirement for about $25-50 \mu \mathrm{g}$ DNA. Clearly, the methodology can be used for measurement of excretion of repair products in urine (Faure et al. 1993, 1998; Bianchini et al. 1998), but has not been used extensively for this purpose. There is no doubt that the GC-MS technique has provided most of the knowledge regarding the basic chemistry of the oxidative modification to DNA, pioneered by Miral Dizdaroglu (Chemical Science and Technology Laboratory, National Institute of Standards and Technology,
Gaithersburg, MD, USA) and Jean Cadet (Laboratoire Lesions des Acid Nucleiques DFRMC/SESAM, Centre d'Etudes Nuclearis, Grenoble, France). In biology, and particularly in vivo, the value of the GC-MS methodology has not been tested to the same extent it has in chemistry, and as stated earlier there appear to be problems with artifacts when preparing tissue samples for the GC-MS procedure that have not been completely solved. If there really are artifacts in this or other procedures the chemical data will naturally still hold true. In particular, the high temperatures during the derivatization process before GC-MS can induce artificial oxidation of non-oxidized bases and nucleosides (Hofer \& Moller, 1998). Probably these problems are not relevant for measurements in urine in which there are few non-oxidized bases compared with tissue where there are a of the order of $10^{5}$ non-oxidized bases per oxidized base; in the latter situation artificial oxidation of just one base $/ 10^{5}$ bases will introduce considerable artifacts.

\section{Liquid chromatography-mass spectrometry methods}

From a theoretical point of view the combination of HPLC separation, ion spray and MS is attractive because it has the potential for analysis of multiple DNA modifications without using the hydrolysis-derivatization-high temperature steps necessary for GC-MS. We have been able to obtain fast analysis and suitable sensitivity with liquid chromatography (LC)-tandem MS for the analysis of 8-oxodG in urine (Poulsen et al. 1999b), and so has another group (Ravanat et al. 1998), and we are now also able to analyse cellular DNA for both 8-oxodG and the corresponding hydroxylated adenosine. Preliminary investigations have shown close agreement between HPLC-EC and liquid chromatography-tandem MS measurements on oxidized nuclear DNA (HE Poulsen and S Loft, unpublished results). Presently, although attractive, the benefits of the methodology need to be proven, just as the sensitivity needs to be determined. As with GC-MS, it is a procedure that requires expensive equipment, skilled and expert staff, and synthesis of isotopically-labelled internal standards. 


\section{${ }^{32} \mathrm{P}$ post-labelling}

${ }^{32} \mathrm{P}$ post-labelling combined with HPLC has been used to estimate oxidative DNA damage (Cadet et al. 1993; Moller et al. 1993; Zeisig \& Moller, 1997). However, so far there are no reports on the systematic use of the developed methodology in biological settings. The advantage of the methodology is the very high sensitivity, since only $1 \mu \mathrm{g}$ DNA is needed to determine one oxidized base per $10^{6}$ bases (Cadet et al. 1993). However, problems have been reported, e.g. artificial oxidation, that still need to be solved (Moller \& Hofer, 1997; Schuler et al. 1997).

\section{Alkaline elution and the comet assay}

The basic principle for the two assays relies on the structural changes to DNA under alkaline conditions. Alkaline elution (Epe, 1995; Pflaum et al. 1997, 1998) is based on a detection system, (e.g. incorporation of $\left[{ }^{3} \mathrm{H}\right]$-thymidine into DNA), followed by elution through filters or a similar device that will allow small DNA fragments to elute differently from large DNA fragments. Simple measurements of radioactivity will give information on DNA strand breaks. In the comet assay cells are placed on a gel, lysed and placed in an electrophoretic field. Undamaged DNA will not be able to move in the gel, and strand breaks or changes in the supercoiling will allow DNA to extend in the electrophoretic field. After staining with a DNA dye (e.g. the fluorescent DNA dye YOYO1) the cellular DNA will appear as a 'comet', and the amount of DNA in the tail will provide information about the DNA damage (Collins et al. 1995).

Alkaline elution technique has the limitation that live cells which will incorporate $\left[{ }^{3} \mathrm{H}\right]$ thymidine are needed, and for the comet assay storage of cells and induction of DNA damage during isolation of cells from organs is not controlled. The sensitivity of the assay is exceptional and for the comet assay only a few hundred cells are needed.

Although a close correlation between the cellular DNA-8-oxodG and the comet assay has been demonstrated (Deng et al. 1997), the specificity of both the alkaline elution method and the comet assay is low. By the use of specific repair enzymes that will induce strand breaks corresponding to specific DNA modifications, the specificity of the assays can be increased (Epe \& Hegler, 1994; Haring et al. 1994; Collins et al. 1995, 1997b; Ross et al. 1995; Tuo et al. 1996; Pflaum et al. 1997).

It is evident that the distribution of the DNA modification is important in the two assays. Imagine two extreme situations. The first is the case where the DNA modification is evenly distributed along the DNA chain and the second where all modifications are on neighbouring guanine moieties. In the first situation the fragments or breaks will easily be detected, in the second that damage will not be detected by either assay because it will correspond to a single lesion. A quantitative analysis of this problem has not been done; however, it could lead to underestimation of the damage, e.g. compared with chemical determination after hydrolysis of DNA where the distribution pattern of damage has no importance.

\section{Immunologically-based methods}

From many points of view an antibody that specifically recognizes, for example, 8-oxodG would be extremely useful. Such approaches have been attempted for measurements in urine, in DNA isolated from tissues and for immunohistochemistry; however, it has been extremely difficult to obtain a sufficiently specific antibody (for example, see Prieme et al. 1996), and presently there does not appear to be an antibody available with sufficient specificity. Data obtained in quantitative measurements with antibodies against 8-oxodG should be interpreted with caution.

\section{Interpretation of urinary repair-product excretion and tissue levels}

Particular attention should be given to the differences in measuring tissue levels and urinary excretion. Tissue levels will provide information about the concentration of modified bases. The observed level will be the result of the formation of new DNA modifications and their removal. An increase or a decrease in the level in a tissue or a population of cells can therefore be due either to an increase in formation, e.g. by induced oxidative stress, or derived from a change in repair of oxidative modifications. Without further information it is not possible to distinguish between the two possibilities or a combination of these possibilities. Urinary excretion of oxidatively-modified bases or nucleosides is the result of repair of these lesions in DNA, excretion into the plasma and elimination into urine. The variable measured is the number of repaired lesions per unit time unit. Assuming a steady-state, i.e. no change in the level of modifications in DNA during the period of investigation, formation and elimination of modifications in DNA must be equal, consequently the urinary measurement is a measure of the rate of formation of new DNA modifications per time unit and is independent of repair. If, for example, repair rates changed, then a new steady-state would be achieved and mass balance, (i.e. formation and elimination), would still be maintained, and again it can be argued that the measurement is independent of repair.

Another difference between the two measurements should also be given consideration. Tissue or cell measurements will provide information for a particular organ, which preferably should be the target organ of interest. Often, in human experiments, surrogate cells such as lymphocytes are investigated, and it is presently unknown if their mode of response is identical to that of the target tissues, and if extrapolation between lymphocytes and target tissues is valid. Urinary measurement, on the other hand, is an average measure of the response of the organism investigated, and as such, large changes in a small organ could be overlooked.

The renal excretion of 8-oxodG occurs with a half-life of a few hours (Loft et al. 1995). Animal experiments have been performed in which both urinary and target organ tissue levels have been measured, and the findings support the notions put forward here. Further details can be found elsewhere (Poulsen et al. 1999a). 
When designing an experiment it is therefore of great importance to consider the experimental conditions and hypotheses in order to chose the optimum type of measurement.

\section{Exercise, oxidative DNA damage and antioxidant intervention}

The notion that exercise leads to the generation of excess free radical dates back to the early 1980s (Lovlin et al. 1987). The notion was put forward that peroxidation of membrane lipids, particularly during re-oxygenation of hypoxic tissues, induced a number of changes in cell functions, clearly demonstrated to include oxidative damage to DNA lipids and proteins (Mecocci et al. 1999). The original ideas also included the possibility that damage to muscles, in particular from exercise, elicited reparative and compensatory mechanisms that would overcompensate, thus resulting at a later stage in muscle proliferation. Exercise has been shown to induce DNA damage to polymorphonuclear leucocytes $1 \mathrm{~d}$ after a half-marathon (Niess et al. 1998), but only slight changes $15 \mathrm{~min}$ after $90 \mathrm{~min}$ of swimming $(1500 \mathrm{~m})$ or running for $70 \mathrm{~min}(15 \mathrm{~km}$; Inoue et al. 1998), and no change after rowing to exhaustion (Nielsen et al. 1995). When comparing habitual longdistance runners and untrained healthy subjects no difference was found in the urinary excretion of 8-oxodG (Pilger et al. 1997). A carefully-designed experiment with monitoring over a period of up to $5 \mathrm{~d}$ after a short-distance triathlon by habitual athletes $(1.5 \mathrm{~km}$ swimming, $40 \mathrm{~km}$ cycling and $10 \mathrm{~km}$ running) showed DNA damage that reached a maximum $3 \mathrm{~d}$ after the exercise, as measured by the comet assay, but showed no differences in micronuclei or in urinary excretion of 8-oxodG (Hartmann et al. 1998). As mentioned earlier, we found increased urinary excretion of 8-oxodG after $30 \mathrm{~d}$ of vigorous exercise for $11-18 \mathrm{~h} / \mathrm{d}$ (Poulsen et al. 1996). Similar findings were obtained during an $8 \mathrm{~d}$ long-distance-running training camp, but the levels in lymphocyte DNA were unchanged (Okamura et al. 1997). Treadmill running to exhaustion produced more DNA damage, as measured by the comet assay, in untrained men compared with trained men (Niess et al. 1996), and training after myocardial infarction abolished the pre-training increase in plasma $\mathrm{H}_{2} \mathrm{O}_{2}$ concentration (Deskur et al. 1998).

The pattern from these observations appears to be quite consistent; immediately after exercise, irrespective of the intensity, there does not appear to be any signs of oxidative damage to DNA. Acute or continued moderate exercise do not produce signs of oxidative DNA damage, and might even be associated with lowering of the levels of oxidation of tissue DNA. However, after long-duration intense exercise there is an increase in oxidative DNA modification. Furthermore, it also appears that compared with a sedentary condition, a trained condition can diminish the effects of an exercise episode. The mechanism(s) by which the trained subject improves the handling of $\mathrm{O}_{2}$ and ROS is not known, and from a quantitative point of view it is not clear how important these changes in oxidation of cellular macromolecules are among all the changes that exercise induces.
One possible mechanism by which increased control of oxidative processes could be achieved would be optimization of dietary-dependent antioxidant substances. Beneficial effects of such an intervention are indicated by the observed oxidation of blood GSH and vitamin $\mathrm{C}$, indicated by increases in GSSG and dehydroascorbic acid, even though the total vitamin $\mathrm{C}$ concentration increased (Viguie et al. 1993). Vitamin E and vitamin C levels are decreased in muscle and increased in plasma with endurance training (Goldfarb, 1993), and total serum antioxidant capacity is elevated (Child et al. 1998). These findings suggest that antioxidants are shifted from tissue to plasma during exercise and that insufficient antioxidant defence systems may exist. Supplementation trials have given variable results (Witt et al. 1992; Hartmann et al. 1995; Packer, 1997; Sumida et al. 1997; Kaikkonen et al. 1998; Kanter, 1998), but rather than improving performance such intervention may be of importance in the long term, i.e. preventing disease in the long term.

The observations of free oxygen radicals acting in signal transduction pathways may play an important role in a variety of cellular responses to exercise. Cellular defence mechanisms could be induced by this type of mechanism, e.g. enzymic antioxidant activities, heat-shock proteins or unknown systems. In this respect, a similar situation has been described in radiobiology, where a small dose of radiation protects against a subsequent large radiation dose (Sadekova et al. 1997), and it should be borne in mind that radiation also works by inducing oxidative stress by cleavage of water with the production of hydroxyl radicals (Dizdaroglu \& Bergtold, 1986).

In summary, the data on relationships between exercise and oxidative DNA modification lead to the hypothesis that there is a U-shaped curve relationship between oxidative DNA modification and the duration and intensity of exercise. If this relationship can be demonstrated and verified it implies that there is an optimal duration and intensity of exercise. The methodologies for measuring oxidative DNA modifications are adequate to establish such a maximum.

\section{References}

Adelman R, Saul RL \& Ames BN (1988) Oxidative damage to DNA: Relation to species metabolic rate and life span. Proceedings of the National Academy of Sciences USA 85, 2706-2708.

Ames BN \& Saul RL (1986) Oxidative DNA damage as related to cancer and ageing. In Principles and Mechanism of Action, p. 11 New York: Alan R Liss Inc.

Ames BN \& Shigenaga MK (1992) Oxidants are a major contributor to aging. Annals of the New York Academy of Sciences 663, 85-96.

Ames BN, Shigenaga MK \& Hagen TM (1993) Oxidants, antioxidants, and the degenerative diseases of aging. Proceedings of the National Academy of Sciences USA 90, 7915-7922.

Bessho T, Tano K, Kasai H, Ohtsuka E \& Nishimura S (1993) Evidence for two DNA repair enzymes for 8-hydroxyguanine (7,8-dihydro-guanine) in human cells. Journal of Biological Chemistry 268, 19416-19421. 
Bianchini F, Donato F, Faure H, Ravanat JL, Hall J \& Cadet J (1998) Urinary excretion of 5-(hydroxymethyl) uracil in healthy volunteers: effect of active and passive tobacco smoke. International Journal of Cancer 77, 40-46.

Cadet J, Incardona MF, Odin F, Molko D, Mouret JF, Polverelli M, Faure H, Ducros V, Tripier M \& Favier A (1993) Measurement of oxidative base damage to DNA by using HPLC-32P-postlabelling and GC/MS-selective ion monitoring assays. In IARC Scientific Publications, pp. 271-276. Lyon, France: IARC.

Cadet J, Ravanat JL, Buchko GW, Yeo HC \& Ames BN (1994) Singlet oxygen DNA damage: chromatographic and mass spectrometric analysis of damage products. Methods in Enzymology 234, 79-88.

Chance B, Sies H \& Boveris A (1979) Hydroperoxide metabolism in mammalian organs. Physiology Review 59, 527-605.

Child RB, Wilkinson DM, Fallowfield JL \& Donnelly AE (1998) Elevated serum antioxidant capacity and plasma malondialdehyde concentration in response to a simulated halfmarathon run. Medicine and Science in Sports and Exercise 30, $1603-1607$.

Collins A, Cadet J, Epe B \& Gedik C (1997a) Problems in the measurement of 8-oxoguanine in human DNA. Report of a workshop, DNA oxidation, held in Aberdeen, UK, 19-21 January, 1997. Carcinogenesis 18, 1833-1836.

Collins AR, Ai-guo M \& Duthie SJ (1995) The kinetics of repair of oxidative DNA damage (strand breaks and oxidised pyrimidines) in human cells. Mutation Research 336, 69-77.

Collins AR, Dobson VL, Dusinska M, Kennedy G \& Stetina R (1997b) The comet assay: what can it really tell us? Mutation Research 375, 183-193.

Collins AR, Dusinska M, Gedik CM \& Stetina R (1996) Oxidative damage to DNA: do we have a reliable biomarker? Environmental Health Perspectives 104, Suppl. 3, 465-469.

Deng XS, Tuo J, Poulsen HE \& Loft S (1997) 2-Nitropropaneinduced DNA damage in rat bone marrow. Mutation Research 391, 165-169.

Deskur E, Przywarska I, Dylewicz P, Szczesniak L, Rychlewski T, Wilk M \& Wysocki H (1998) Exercise induced increase in hydrogen peroxide plasma levels is diminished by endurance training after myocardial infarction. International Journal of Cardiology 67, 219-224.

Dizdaroglu M (1985) Formation of an 8-hydroxyguanine moiety in deoxyribonucleic acid on gamma-irradiation in aqueous solution. Biochemistry 24, 4476-4481.

Dizdaroglu M (1991) Chemical determination of free radicalinduced damage to DNA. Free Radicals in Biology and Medicine 10, 225-242.

Dizdaroglu M (1992) Oxidative damage to DNA in mammalian chromatin. Mutation Research 275, 331-342.

Dizdaroglu M (1993) Chemistry of free radical damage to DNA and nucleoproteins. In DNA and Free Radicals, pp. 19-39 [B Halliwell, editor]. Chichester, West Sussex: Ellis Horwood Ltd.

Dizdaroglu M (1994) Chemical determination of oxidative DNA damage by gas chromatography-mass spectrometry. Methods in Enzymology 234, 3-16.

Dizdaroglu M \& Bergtold DS (1986) Characterization of free radical-induced base damage in DNA at biological relevant levels. Analytical Biochemistry 156, 182-188.

Epe B (1995) DNA damage profiles induced by oxidizing agents. Reviews in Physiology, Biochemistry and Pharmacology 127, 223-249.

Epe B \& Hegler J (1994) Oxidative DNA damage: endonuclease fingerprinting. Methods in Enzymology 234, 122-131.

Erikssen G, Liestøl K, Bjørnholt E, Thaulow E, Sandvik L, Erikssen J \& Aach RD (1998) Changes in physical fitness and changes in mortality. Lancet 352, 759-762.
Esterbauer H, Gebicki J, Puhl H \& Jurgens G (1992) The role of lipid peroxidation and antioxidants in oxidative modification of LDL. Free Radicals in Biology and Medicine 13, 341-390.

Faure H, Incardona MF, Boujet C, Cadet J, Ducros V \& Favier A (1993) Gas chromatographic-mass spectrometric determination of 5-hydroxymethyluracil in human urine by stable isotope dilution. Journal of Chromatography 616, 1-7.

Faure H, Mousseau M, Cadet J, Guimier C, Tripier M, Hida H \& Favier A (1998) Urine 8-oxo-7,8-dihydro-2-deoxyguanosine vs. 5-(hydroxymethyl) uracil as DNA oxidation marker in adriamycin-treated patients. Free Radical Research 28, 377382.

Goldfarb AH (1993) Antioxidants: role of supplementation to prevent exercise-induced oxidative stress. Medicine and Science in Sports and Exercise 25, 232-236.

Halliwell B (1994) Free radicals, antioxidants, and human disease: curiosity, cause or consequence. Lancet 344, 721-724.

Haring M, Rudiger H, Demple B, Boiteux S \& Epe B (1994) Recognition of oxidized abasic sites by repair endonucleases. Nucleic Acids Research 22, 2010-2015.

Hartmann A, Niess AM, Grunert-Fuchs M, Poch B \& Speit G (1995) Vitamin E prevents exercise-induced DNA damage. Mutation Research 346, 195-202.

Hartmann A, Pfuhler S, Dennog C, Germadnik D, Pilger A \& Speit G (1998) Exercise-induced DNA effects in human leukocytes are not accompanied by increased formation of 8-hydroxy-2'-deoxyguanosine or induction of micronuclei. Free Radicals in Biology and Medicine 24, 245-251.

Hofer T \& Moller L (1998) Reduction of oxidation during the preparation of DNA and analysis of 8-hydroxy2 '-deoxyguanosine. Chemical Research in Toxicology 11, $882-887$.

Inoue T, Zhouseng M, Sumikawa K, Adachi K \& Okochi T (1998) Effect of physical exercise on the content of 8-hydroxydeoxyguanosine in nuclear DNA prepared from human lymphocytes. Japanese Journal of Cancer Research 84, 725-750.

Kaikkonen J, Kosonen L, Nyyssonen K, Porkkala-Sarataho E, Salonen R, Korpela H \& Salonen JT (1998) Effect of combined coenzyme Q10 and D-alpha-tocopheryl acetate supplementation on exercise-induced lipid peroxidation and muscular damage: a placebo-controlled double-blind study in marathon runners. Free Radical Research 29, 85-92.

Kanter M (1998) Free radicals, exercise and antioxidant supplementation. Proceedings of the Nutrition Society 57, 9-13.

Kasai H (1997) Analysis of a form of oxidative DNA damage, 8hydroxy-2'-deoxyguanosine, as a marker of cellular oxidative stress during carcinogenesis. Mutation Research 387, 147-163.

Kasai H \& Nishimura S (1984) Hydroxylation of deoxyguanosine at the C-8 position by ascorbic acid and other reducing agents. Nucleic Acids Research 12, 2137-2145.

Kiningham RB (1998) Physical activity and the primary prevention of cancer. Primary Care 25, 515-536.

Lee IM, Paffenbarger RS \& Hennekens CH (1997) Physical activity, physical fitness and longevity. Aging 9, 2-11.

Loft S, Larsen PN, Rasmussen A, Fischer-Nielsen A, Bondesen S, Kirkegaard P, Rasmussen LS, Ejlersen E, Tornoe K, Bergholdt R \& Poulsen HE (1995) Oxidative DNA damage after transplantation of the liver and small intestine in pigs. Transplantation 59, 16-20.

Loft S \& Poulsen HE (1996) Cancer risk and oxidative DNA damage in man. Journal of Molecular Medicine 74, 297-312. (Published erratum in Journal of Molecular Medicine (1997), 75, 67-68).

Loft S \& Poulsen HE (1998) Markers of oxidative damage to DNA: antioxidants and molecular damage. Methods in Enzymology 300, 166-184. 
Loft S, Vistisen K, Ewertz M, Tjonneland A, Overvad K \& Poulsen HE (1992) Oxidative DNA damage estimated by 8-hydroxydeoxyguanosine excretion in humans: influence of smoking, gender and body mass index. Carcinogenesis 13, 2241-2247.

Lovlin R, Cottle W, Pyke I, Kavanagh M \& Belcastro AN (1987) Are indices of free radical damage related to exercise intensity. European Journal of Applied Physiology and Occupational Physiology 56, 313-316.

Lunec J (1999) ESCODD: European Standards Committee on Oxidative DNA Damage. Free Radical Research (In the Press).

Mecocci P, Fano G, Fulle S, MacGarvey U, Shinobu L, Polidori M, Cherubini A, Vecchiet J, Senin U \& Beal MF (1999) Agedependent increases in oxidative damage to DNA, lipids, and proteins in human skeletal muscle. Free Radicals in Biology and Medicine 26, 303-308.

Moller L \& Hofer T (1997) [32P]ATP mediates formation of 8hydroxy-2'-deoxyguanosine from 2 -deoxyguanosine, a possible problem in the 32P-postlabelling assay. Carcinogenesis 18, 2415-2419.

Moller L, Zeisig M \& Vodicka P (1993) Optimization of an HPLC method for analyses of 32P-postlabelled DNA adducts. Carcinogenesis 14, 1343-1348.

Nielsen HB, Hanel B, Loft S, Poulsen HE, Pedersen BK, Diamant M, Vistisen K \& Secher NH (1995) Restricted pulmonary diffusion capacity after exercise is not an ARDS-like injury. Journal of Sports Sciences 13, 109-113.

Niess AM, Baumann P, Roecker K, Mayer F \& Dickhuth HH (1998) Effects of intensive endurance exercise on DNA damage in leucocytes. Journal of Sports Medicine and Physical Fitness 38, 111-115.

Niess AM, Hartmann A, Grunert-Fuchs M, Poch B \& Speit G (1996) DNA damage after exhaustive treadmill running in trained and untrained men. International Journal of Sports Medicine 17, 397-403.

Okamura K, Doi T, Hamada K, Sakurai M, Yoshioka Y, Mitsuzono R, Migita T, Sumida S \& Sugawa KY (1997) Effect of repeated exercise on urinary 8-hydroxy-deoxyguanosine excretion in humans. Free Radical Research 26, 507-514.

Oliveria SA \& Christos PJ (1997) The epidemiology of physical activity and cancer. Annals of the New York Academy of Sciences 833, 79-90.

Packer L (1997) Oxidants, antioxidant nutrients and the athlete. Journal of Sports Sciences 15, 353-363.

Paffenberger RS, Hyde RT, Wing AL, Lee IM, Jung DL \& Kampert JB (1993) The association of changes in physical-activity level and other lifestyle characteristics with mortality among men. New England Journal of Medicine 328, 538-545.

Palmer HJ \& Paulson KE (1997) Reactive oxygen species and antioxidants in signal transduction and gene expression. Nutrition Reviews 55, 353-361.

Pedersen BK, Rohde T \& Zacho M (1996) Immunity in athletes. Journal of Sports Medicine and Physical Fitness 36, 236-245.

Pflaum M, Kielbassa C, Garmyn M \& Epe B (1998) Oxidative DNA damage induced by visible light in mammalian cells: extent, inhibition by antioxidants and genotoxic effects. Mutation Research 408, 137-146.

Pflaum M, Will O \& Epe B (1997) Determination of steady-state levels of oxidative DNA base modifications in mammalian cells by means of repair endonucleases. Carcinogenesis $\mathbf{1 8}$, 2225-2231.

Pilger A, Germadnik D, Formanek D, Zwick H, Winkler N \& Rudiger HW (1997) Habitual long-distance running does not enhance urinary excretion of 8-hydroxydeoxyguanosine. European Journal of Applied Physiology and Occupational Physiology 75, 467-469.
Poulsen HE, Loft S, Prieme H, Vistisen K, Lykkesfeldt J, Nyyssonen K \& Salonen JT (1999a) Oxidative DNA damage in vivo: Relationship to age, plasma antioxidants, drug metabolism, glutathione-S-transferase activity and urinary creatinine excretion. Free Radical Research (In the Press).

Poulsen HE, Loft S \& Vistisen K (1996) Extreme exercise and oxidative DNA modification. Journal of Sports Sciences 14, 343-346.

Poulsen HE, Prieme H \& Loft S (1998a) Role of oxidative DNA damage in cancer initiation and promotion. European Journal of Cancer Prevention 7, 9-16.

Poulsen HE, Weimann A \& Loft S (1999b) Urinary measurement of 8-oxodG (8-oxo-2'-deoxyguanosine). In Handbook of Clinical Analysis: In Vivo Damage to Biomolecules. [J Lunec, editor]. London: John Wiley and Sons Ltd (In the Press).

Poulsen HE, Weimann A, Salonen JT, Nyyssonen K, Loft S, Cadet J, Douki T \& Ravanat JL (1998b) Does vitamin C have a prooxidant effect? Nature 395, 231-232.

Prieme H, Loft S, Cutler RG \& Poulsen HE (1996) Measurement of oxidative DNA injury in humans: evaluation of a commercially available ELISA assay. In Natural Antioxidants and Food Quality in Atherosclerosis and Cancer Prevention, pp. 78-82 [JT Kumpulainen, editor]. London: The Royal Society of Chemistry.

Ravanat JL, Duretz B, Guiller A, Douki T \& Cadet J (1998) Isotope dilution high-performance liquid chromatography-electrospray tandem mass spectrometry assay for the measurement of 8-oxo7,8-dihydro-2'-deoxyguanosine in biological samples. Journal of Chromatography 715, 349-356.

Ravanat JL, Turesky RJ, Gremaud E, Trudel LJ \& Stader RH (1995) Determination of 8-oxoguanine in DNA by gas chromatography-mass spectrometry and HPLC-electrochemical detection: overestimation of the background level of the oxidized base by the gas chromatography-mass spectrometry assay. Chemical Research in Toxicology 8, 1039-1045.

Retèl J, Hoebee B, Braun JEF, Lutgerink JT, van den Akker E, Wanamarta AH, Joneje H \& Lafleur MVM (1993) Mutational specificity of oxidative DNA damage. Mutation Research 299, 165-182.

Ross GM, McMillan TJ, Wilcox P \& Collins AR (1995) The single cell microgel electrophoresis assay (comet assay): technical aspects and applications. Report on the 5th LH Gray Trust Workshop, Institute of Cancer Research, 1994. Mutation Research 337, 57-60.

Sadekova S, Lehnert S \& Chow TY (1997) Induction of PBP74/mortalin/Grp75, a member of the hsp70 family, by low doses of ionizing radiation: a possible role in induced radioresistance. International Journal of Radiation Biology 72, 653-660.

Schuler D, Otteneder M, Sagelsdorff P, Eder E, Gupta RC \& Lutz WK (1997) Comparative analysis of 8-oxo-2'-deoxyguanosine in DNA by 32P- and 33P-postlabelling and electrochemical detection. Carcinogenesis 18, 2367-2371.

Shigenaga MK, Gimeno CJ \& Ames BN (1989) Urinary 8-hydroxy-2'-deoxyguanosine as a biological marker of in vivo oxidative DNA damage. Proceedings of the National Academy of Sciences USA 86, 9697-9701.

Sumida S, Doi T, Sakurai M, Yoshioka Y \& Okamura K (1997) Effect of a single bout of exercise and beta-carotene supplementation on the urinary excretion of 8-hydroxydeoxyguanosine in humans. Free Radical Research 27, 607-618.

Tuo J, Loft S, Thomsen MS \& Poulsen HE (1996) Ex vivo time-dependent cell DNA-degradation shown by single cell gel electrophoresis. Pharmacology and Toxicology 78, 55-57.

Viguie CA, Frei B, Shigenaga MK, Ames BN, Packer L \& Brooks GA (1993) Antioxidant status and indexes of oxidative stress 
during consecutive days of exercise. Journal of Applied Physiology 75, 566-572.

Wiseman H \& Halliwell B (1996) Damage to DNA by reactive oxygen and nitrogen species: role in inflammatory disease and progression to cancer. Biochemical Journal 313, 17-29.

Witt EH, Reznick AZ, Viguie CA, Starke-Reed P \& Packer L (1992) Exercise, oxidative damage and effects of antioxidant manipulation. Journal of Nutrition 122, 766-773.
Zeisig M \& Moller L (1997) 32P-Postlabelling high-performance liquid chromatographic improvements to characterize DNA adduct stereoisomers from benzo[a]pyrene and benzo[c]phenanthrene, and to separate DNA adducts from 7,12dimethylbenz[a]anthracene. Journal of Chromatography 691B, 341-350. 